University of Nebraska - Lincoln

DigitalCommons@University of Nebraska - Lincoln

2000

\title{
Some Post-Pliocene Buried Soils of Central United States
}

James Thorp

W. M. Johnson

E. C. Reed

University of Nebraska - Lincoln

Follow this and additional works at: https://digitalcommons.unl.edu/conservationsurvey

Part of the Geology Commons, Geomorphology Commons, Hydrology Commons, Paleontology

Commons, Sedimentology Commons, Soil Science Commons, and the Stratigraphy Commons

Thorp, James; Johnson, W. M.; and Reed, E. C., "Some Post-Pliocene Buried Soils of Central United States" (2000). Conservation and Survey Division. 681.

https://digitalcommons.unl.edu/conservationsurvey/681

This Article is brought to you for free and open access by the Natural Resources, School of at DigitalCommons@University of Nebraska - Lincoln. It has been accepted for inclusion in Conservation and Survey Division by an authorized administrator of DigitalCommons@University of Nebraska - Lincoln. 


\title{
SOME POST-PLIOCENE BURIED SOILS OF CENTRAL UNITED STATES
}

\author{
JAMES THORP, W. M. JOHNSON, AND E. C. REED
}

WITH 2 PLATES

\section{Introduction}

Practically all Pleistocene geologists and soil scientists have noted the wide occurrence of buried soils at several stratigraphic positions, some strongly developed, and some with profiles that could have developed in a few hundred years. Many buried soils were partly eroded before burial, and some of their horizons are missing or truncated from place to place. In some, only the leached and weathered parent material remains as evidence of a long period of soil formation.

This paper touches on buried soils in central United States from the southern border of the Mankato (last glacial) drift to the Gulf of Mexico, and from the Appalachian Mountains west to the Rocky Mountains. Emphasis is on the buried soils of Nebraska, Iowa, Illinois, Missouri, and Kansas where considerable work has been done in recent years. Co-author Johnson is collecting profile descriptions and is analysing samples of the buried soils in order better to estimate the conditions under which they developed. His findings will be collected later in a thesis connected with his graduate studies at the University of Nebraska.

Although buried soils have long been known in central United States, and much has been written about them, we find little published information on the details of profile characteristics. The strongly developed buried soils in the glaciated and periglacial areas were formed primarily during interglacial stages of the Pleistocene. Weakly developed buried soils, especially notable in the late Pleistocene loess, may or may not be related to fluctuations of the Wisconsin ice front. A brief review of selected references outlines previous work and suggests the need for more detailed studies.

\section{Previous Work}

Fossil soils were first recognized and described probably in the late I80o's, at about the same time that the study of soils began to develop into a true scientific discipline. Glinka and Krasnov (cited by Polynov, 1927) studied so-called 'two-stage' soils in the Transcaucasian region and concluded that the underlying red-coloured materials are the products of ancient weathering of a lateritic or red-soil type. The present climatic and biological environment of that region favours the podzolization process. Glinka hypothesized a sub-tropical environment in Tertiary (actually, probably early Pleistocene) time that produced a red soil high in sesquioxides and a change from that environment to the present one during and following the Pleistocene.

According to Polynov (1927), the first observations of true buried or 
fossil soils were those of Feofilaktov in the loesses of the Lubny district, Poltava Government. Similar buried soils were noted in Ukrainia in the region of the Don River, in other parts of Russia, and in Poland. Krokos (1926, 1927) made detailed studies of the loesses and fossil soils of Ukrainia. On the basis of stratigraphic and pedologic evidence he correlates three fossil soils with interglacials following the retreat of Günz, Mindel, and Riss glaciers, respectively, and postulates that the two older interglacial stages represent times of more humid climate than the latest interglacial or the present climate.

The earliest observations of fossil soils in North America were made by geologists. Only in comparatively recent years have North American soil scientists become interested in the study of buried profiles. Worthen (r866) was perhaps the first to recognize that a definite soil 'horizon' separates the Illinois till from the overlying loess. Later Leverett (I898c) suggested the name Sangamon for this weathered (soil) zone. Leverett (I898 $b$ and $c$ ) also proposed names for two other weathered zones or fossil soils, Yarmouth for the one between the Kansas and Illinois tills, and Peoria for one between the Iowa loess and the Shelbyville till. In time the interpretation of these names changed so that some authors now use the name Sangamon for the loess that was deposited during the retreat of the Illinois glacier, Yarmouth for the late-glacial alluvium and loess that overlap the Kansan till, and Peoria for the loess deposited following Iowan glaciation, exclusive of the late-Wisconsin (Condra et al., r947).

A complete review of the literature relating to North American buried soils is not presented here. Most of the work on these ancient soils has been done by geologists, and most of it has been directed towards one or both of two aims: to establishment of a stratigraphic datum (W. Bryan, 1939; Condra et al., 1947; Frye 1949; Frye et al., I949; Kay, I939; Kay et al., 1928, 1943, 1920; Movius, 1949; Peltier, I949; Schultz and Stout, 1948), and to interpretation of the climatic and physiographic history of an area (K. Bryan, I948; Bryan and Albritton, 1943; Leighton and MacClintock, I930; Lugn, I935; Schultz and Stout, I945; Simonson, I94I). The first studies, of which the works of Leverett, Kay, and Leighton provide classic examples, were all within the region of continental glaciation. In the past two decades the observation and study of fossil soils has been extended, first to periglacial deposits and finally to regions entirely without direct influence of glaciation.

The Afton, Yarmouth, Sangamon, and Brady soils are all prominently developed in the State of Kansas, but the Afton soil is exposed in few places. Frye and his co-workers (1949) have made extensive studies of these soils, using stratigraphic, petrographic, and paleontologic techniques. They have shown that the Sangamon soil serves as a regional stratigraphic datum and furnishes a record of Sangamonian climate over western, central, and north-eastern Kansas. Particularly noteworthy is the fact that contrasts in Sangamon soil character from north-west to south-west exceed contrasts in modern soil profiles, suggesting that there has been a significant change in climate in south-western Kansas since Sangamonian time. The work of A. B. Leonard (1950) on Pleisto- 
cene molluscs supports the pedologic evidence of gradual 'drying-up' of the Great Plains region since Yarmouthian time.

Bryan and Albritton (I943) suggested a technique for using fossil soils and 'complex' (two-stage) soils to interpret past climatic changes. They point out that the most useful paleopedological evidence is likely to be preserved in deposits along the boundaries between humid and semiarid climatic belts, because here relatively small changes in climate are likely to produce striking changes in the soil morphology. They applied this technique to the study of colluvial deposits in the Trans-Pecos area of Texas, and K. Bryan (1948) used it to determine the relative ages of some small volcanoes in the southern part of the Valley of Mexico.

No attempt is made here to enumerate all the places in the world where buried soils have been reported. It is safe to say that fossil soils of determinable age exist everywhere in the world where cataclysmic changes in climate or in rate of deposition of sediments, alluvial and eolian, were associated with glaciation, tectonic movements, \&c. Mohr (1944) reports fossil red earths in Java. Movius (1949) used buried soils on stream terraces as aids to correlation of the ages of Pleistocene terraces in Java, India, and China. Pendleton et al. (I932, 1935) reported fossil soils in the loess deposits of Suiyuan Province and near Harbin, China. Thorp (1935, 1936) gives descriptions of several buried soils in the loesses of north-western China, and reports analyses of some profiles. These Chinese fossil soils are valuable stratigraphic markers there as they are in other parts of the world. Thorp saw many examples of buried soils in the volcanic-ash deposits of Japan and the Philippine Islands.

Johnson found buried soils common in the regions of volcanic-ash deposits and in the terrace deposits of larger streams of Colombia, South America. W. Bryan (1939) suggested that the 'Red Earth Residuals' of Queensland may be used as a stratigraphic datum and as a basis for correlation of some of the land surfaces in Queensland with those in other countries. Fossil soils have been reported and described in Europe (Joffe, r936) and in Africa.

\section{Buried Soils and the Pleistocene Section in Central United States}

Fig. I, outlining the Pleistocene section in central United States, is a recent modification of the original correlation table of Condra et al. (1947, Fig. 6). It shows the four major glaciations-(I) the Nebraskan, (2) the Kansan, (3) the Illinoian, and (4) the Wisconsin-and the major periglacial deposits of the Great Plains. Although each of the four glaciations may have been complex, only the last major glaciation, the Wisconsin, is exposed widely enough and preserved well enough that evidences of minor advances and retreats of the ice can be easily recognized. Sub-stages of the Wisconsin glaciation generally recognized in the United States are, from older to younger, the Iowa, the Tazewell, the Cary, and the Mankato. It is now thought that the Iowa-Tazewell and the Cary-Mankato formed two nearly synchronous pairs, with a significant time interval between the pairs (Fig. $\mathrm{r}$ ). 
The theoretical succession of events is as follows, beginning with the earliest glaciation and continuing to the present:

I. The Nebraskan-Aftonian.-The Nebraska ice sheet advanced as far south as Missouri and north-eastern Kansas and nearly as far west as the Big Blue River in Nebraska. Some gravelly and sandy outwash from the main ice front, and doubtless from the Rocky Mountain glaciers, accumulated during both the advance and retreat of the Nebraska ice

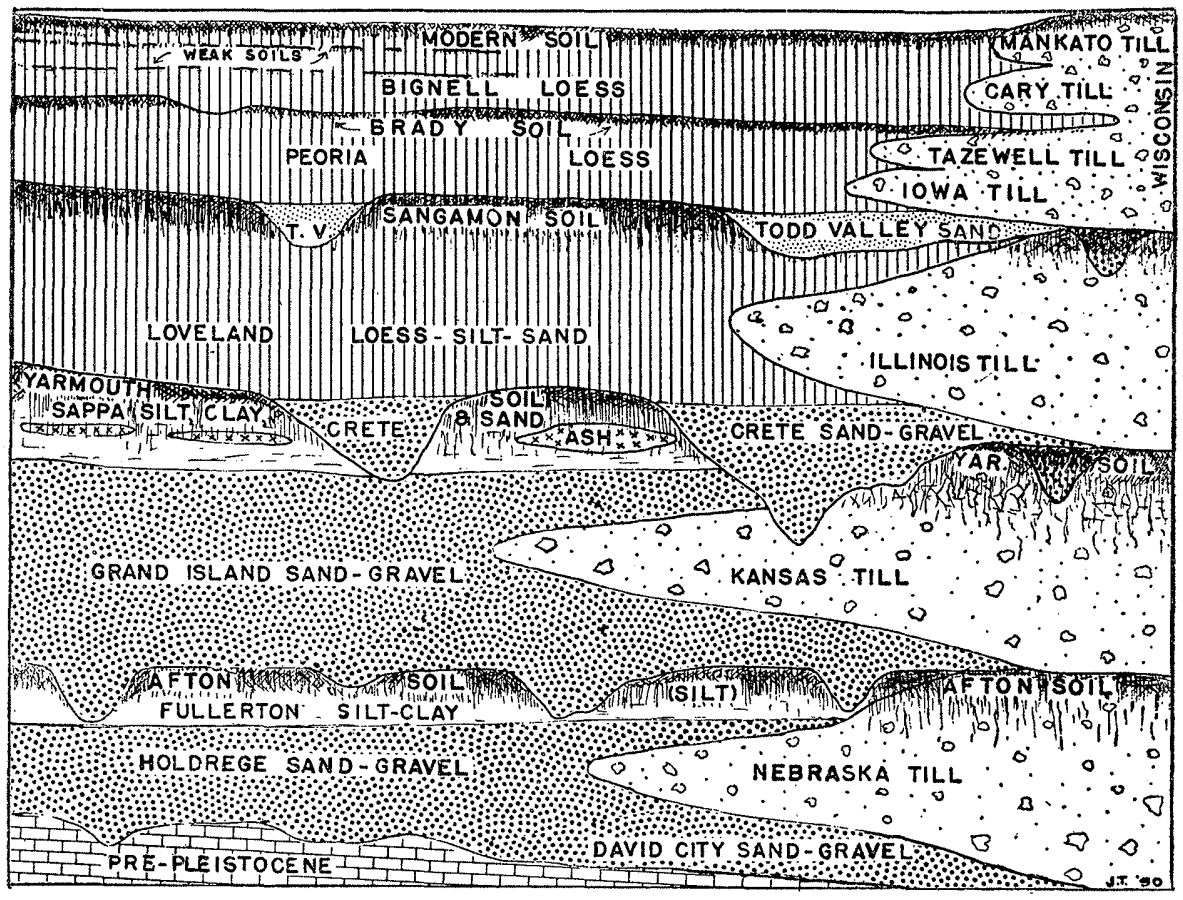

FIG. I. Generalized Pleistocene section of central United States, showing the succession of glacial deposits of north-central States and periglacial deposits as they occur in Nebraska, Kansas, and adjacent areas. Our present interpretation of the relationships of buried soils to Pleistocene deposits is shown.

sheet. The outer edge of the till is interbedded here and there with water-laid sand, gravel, and silt, suggesting fluctuation in the ice front. During the retreat of Nebraska ice, outwash streams carried much silty material which remains partly a stratified and partly an unstratified, probably eolian, deposit. While the name 'Aftonian' has been applied by some workers to the silty late-Nebraskan outwash, it seems more appropriate to reserve the name Afton* for the Nebraskan-Kansan interglacial stage, as did Leverett ( $1898 a$ ).

The melting of Nebraska ice was followed by a very long ice-free

* Throughout this paper place-names are used for formations or deposits and buried soils, and adjective endings are added to these names to apply to time concepts. E.g. 'Afton soil', 'Aftonian time'. 
period of soil formation, the Aftonian Interglacial, during which the calcareous drift was leached to considerable depths, and soils of various kinds were formed. Much of the buried soil, formed during the Aftonian Interglacial, is dark grey, carbonaceous, and clayey in the upper part, and medium grey, tough, plastic, and very clayey in the lower part. The material, as a whole, has been called 'Nebraskan gumbotil' following the introduction of this name by Kay (I9I6). The word 'gumbo', originally an African word for the mucilaginous pods of the okra plant, is a common name among American farmers for any sticky clayey soil that is hard to plough.

Only part of the 'gumbo soil' is developed from glacial till. Much of it was formed entirely in silty alluvial, lacustrine, or eolian deposits. Some of it developed entirely from boulder-clay till; and in many places it is clear that the profile was formed partly in water- or wind-laid deposits and partly in strictly glacial deposits. The true gumbo soil with its grey and mottled gley subsoil, clayey texture, and blocky to massive structure seems to have formed under the influence of a permanent high water-table. Remains of peaty, water-loving plants in the uppermost foot or two confirm poor drainage during formation. Most of the gumbo soil occurs on remnants of an old land surface which, if reconstructed, would have very low relief.

Most of the Nebraska drift with its Aftonian soil was buried so deep beneath later deposits that it crops out only on the slopes of deep valleys, where it causes seepage and landslides during wet weather. Much of the information regarding it comes from a study of subsurface samples taken with drilling equipment used in ground-water exploration. The Conservation and Survey Division, University of Nebraska, and the Geological Survey of Kansas - both co-operating closely with the GroundWater Division of the United States Geological Survey-are leading in this field of study. In Nebraska the gumbo soil is found on uneroded parts of the Nebraska till, on the late Nebraska silt which overlaps it, and on the Fullerton silt and clay of central Nebraska, outside the glaciated area (see Fig. I).

Although the Aftonian interglacial time-interval is known to be represented by the gumbo soil and its catenary associates of several kinds, little is known regarding the age of some of the very old soils outside glaciated areas. Possibly a few of the red and yellow soils-especially the red ones-of southern United States may date back as far as the Aftonian.

2. The Kansan-Yarmouthian.-The Kansas ice sheet advanced over much of the territory covered by the Nebraska ice, but it extended considerably farther in Nebraska and Kansas, some miles beyond the Big Blue River and a short distance south of the Kansas River in several places. The sequence of events was much like that of the Nebraskan glaciation and deglaciation. Fig. 2 shows how the Kansas glacier picked up frozen blocks of Afton soil and incorporated them in the Kansas till.

Late during the Kansas deglaciation there was a tremendous volcanic eruption, or series of eruptions, possibly in north-central New Mexico 
(Swineford, r949). The ash (the Pearlette) from this eruption drifted as far east as central Texas, eastern Kansas and Nebraska, southern Minnesota, north-western Missouri, and north-western Iowa. Some of it accumulated in depressions where it was buried later by the silt, sand, gravel, and clay of the upper part of the Sappa formation (see Fig. I). Since there was apparently only one important ash fall during middle Pleistocene time in central United States, geologists confidently use the Pearlette ash as a stratigraphic marker for late Kansan (Sappan) time.

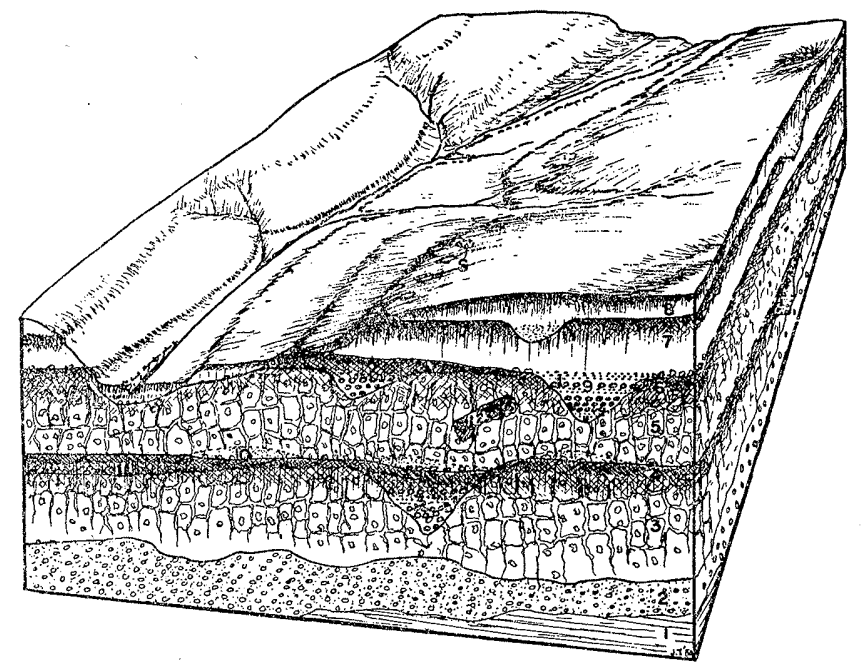

FIG. 2. Block diagram showing succession of Pleistocene deposits and buried soils typical of western Iowa, north-western Missouri, north-eastern Kansas, and southeastern Nebraska. In any given place, one or more of the deposits and the accompanying soils may be lacking; and some of the buried soils may be truncated. Note 'shoulders' or faint scarps where buried soils crop out. Solonetz (S) spots occur at some places near junctions of younger deposits with buried soils.

I. Paleozoic or Mesozoic bedrock. 2. David City (earliest Pleistocene) gravel and sand. 3. Nebraska glacial till and outwash (the first glaciation). 4. Afton soil (first interglacial). 5. Kansas glacial till (the second and maximum glaciation). 6. Yarmouth soil (second interglacial) from Kansas till, outwash, and Sappa sediments. 7. Loveland loess (Illinoian or third glacial age), and Sangamon soil (third interglacial). 8. Peorian and later loess (Wisconsin or fourth glacial age), and modern soil. 9. Crete (early Illinoian age) gravel and sand. Io. Pro-Kansan silt and sand. I I. 'Afton silt' (late Nebraskan age). I2. Block of Aftonian-aged soil in Kansas glacial till.

A long period of soil formation, the Yarmouthian Interglacial, followed the retreat of Kansas ice and the deposition of the Pearlette ash and other stratified materials of the Sappa formation (the 'Upland' of Lugn, r935). This gave rise to the Yarmouth soils, part of which Kay and Apfel (I928, p. I30), called 'Kansan gumbotil', which they said was capped by a 'distinct soil zone' or 'forest bed'.

The Yarmouth soils formed at the surface of whatever land was exposed at the time. Some of this land was well drained and some of it was flat and poorly drained. 'Gumbo' soils developed on the smooth, 
poorly drained areas, and 'normal' or 'zonal' soils with reddish B horizons formed on the well-drained areas. The well-drained catena members are hard to distinguish from soils formed during the Sangamonian Interglacial time. Parent materials included Kansas glacial till, Kansas loess, Kansas outwash of sandy, silty, and clayey textures, and various kinds of bedrock exposed in many parts of the country that were neither reached by glaciers nor covered by loess.

Much of the Yarmouth soil was truncated by erosion and the remnants were buried later by materials of Illinoian and Wisconsinian ages. Buried Yarmouth soils are more of gumbo types (in places with loamy A horizons) than of normal ones, doubtless because the flatter areas were the last to be attacked by erosion and the first to be covered by loess.

3. The Illinoian-Sangamonian.-Following the very long Yarmouthian Interglacial time, the Illinois ice sheet advanced over central United States, but failed to reach large areas in southern Iowa, northern Missouri, eastern Nebraska, and north-eastern Kansas (see Flint's glacial map of North America (National Research Council, I945)). The westward extent of this ice sheet is not fully known, but in northern latitudes according to Alden (1932), it may have extended far out on the Great Plains in South Dakota, North Dakota, Montana, Saskatchewan, and Alberta. In any case, a great deal of Loveland loess and other materials were deposited in periglacial areas during both the advance and retreat of the Illinois ice (see Fig. I). A vast area in Nebraska and Kansas, in eastern Colorado, and southward from Illinois to Louisiana, along the east side of the Mississippi River, was covered by loess, wind-blown sand, or by water-laid gravel and sand during this time. Geologists believe that outwash sediments and some loess were deposited contemporaneously in eastern United States (Peltier, r949). No doubt much alluvium was deposited in southern States, contemporaneous with Illinoian glaciation.

The Sangamonian Interglacial, a very long period of soil formation, followed the retreat of Illinois ice. On the one hand, dark-coloured A horizons suggest that most of the buried Sangamon soils west of the Missouri River in Kansas and Nebraska, and probably farther west, were formed under grassy vegetation. On the other hand, deep leaching, light-coloured podzolized A horizons, and reddish-brown B horizons of many of the buried Sangamon soils in Iowa and Missouri and eastward suggest humid climates and forest cover in that region (Baker, I924; Simonson, r94I).

During and immediately following the long Sangamonian Interglacial, erosion truncated some of the soils, but large areas remained intact.

4. The Wisconsinian-Modern.-The Wisconsin ice spread over an enormous area of North America and covered much, but not all, of the land that had been invaded by the three preceding ice sheets. Large areas of Illinois drift remained uncovered, notably in eastern Iowa and in southern Illinois, Indiana, and Ohio. Loess accumulated during both the advance and retreat of Wisconsin glaciers, especially during the Iowa and Tazewell sub-stages, and, to less extent, during the Cary substage. Little loess accumulated on the Mankato till, but much loess 
outside the drift area has been assigned tentatively to the Mankato substage (Schultz and Stout, I945).

The first Wisconsin loess seems to have collected very slowly on the old Sangamon soil in Nebraska and Kansas. Soil formation kept pace with deposition, and the decay of grass roots darkened the first layers of Wisconsin loess. Dark granular silty A horizons as much as $3 \mathrm{ft}$. thick, or even more, developed in some places before loess began to accumulate too rapidly for soil formation to keep pace. Vertebrate paleontologists call the over-thickened $A$ horizon and the lower part of the overlying loess the 'Citellus zone', named from the small rodents whose skeletons are found preserved in great numbers in this and in lower horizons (Lugn, I935). Ancient rodent burrows (crotovinas) extend from the upper, younger, part of the buried soil profile into the older lower A, B, and $\mathrm{C}$ horizons developed in Loveland loess, and even into the Sappa deposits.*

The thin upper loess of the Citellus zone (Schultz and Stout, r945, I948) of Nebraska, Kansas, and adjacent States may correlate with the Farmdale loess of southern Illinois, which the Pleistocene geologists of Illinois (Leighton and MacClintock, I949) consider to be a pre-Iowan, post-Sangamonian loess.

The Peoria loess, named from Peoria, Illinois, is more recent than the Farmdale loess, and seems to be associated with the Iowa and Tazewell sub-stages of the Wisconsin glaciation.

The greatest and most extensive deposits of loess were made during Iowan and Tazewellian times, both close to the glacier fronts and in more distant areas, especially along the large glacier-fed and trans-plains rivers like the lower Mississippi, the Platte, the Missouri, and the Arkansas, and adjacent to the drier parts of the Great Plains east of the Rocky Mountains. Contemporaneously, a great amount of eolian sand was heaped up in various parts of the Great Plains. The largest dunes are in north-central and south-western Nebraska, where the total area is about I3 to I4 million acres; along the Arkansas River in the vicinity of Great Bend, Kansas; and along the various rivers that flow across the high plains in Oklahoma and Texas.

As far as we know, most of these sand-dunes were formed during the late Pleistocene, although some may be older. Dark-coloured sandy loam soils with reddish-brown sandy clay loam subsoils along the Kaw River, between Topeka and Lawrence, Kansas, are developed from sandy alluvium reworked by the wind at least as early as Illinoian time. $f$ Soils buried within the sand-dunes indicate that dune formation alternates with periods of stability.

We find very few and very weakly developed buried soils within areas of Wisconsin glacial till; but some periglacial loess deposits in Nebraska and Kansas have successions of buried soils that are known to be of Wisconsin age. At least one fairly well-developed Chernozem-like soil

* Verbal information from Dr. C. B. Schultz, Director, University of Nebraska Museum, and field observation by the authors.

+ Verbal opinion given by Dr. John Frye, Executive Director of the Geological Survey of Kansas. 
appears in Nebraska and Kansas at the top of the loess correlated as Peoria (Iowa-Tazewell). Schultz, Stout, and others (Schultz and Stout, I948) have given it the name 'Brady'. Some of it is a Chernozem-like silt loam without textural variation in the profile; and some of it has a mottled subsoil suggesting that it may be a preserved Wiesenboden or Humic-Gley soil. The Bignell loess, that overlies the Brady soil in places, has in it a succession of dark bands or weak soils that represent short periods of pause or slow-down in loess deposition. 'Double soils' with one dark A horizon superimposed over another, and in places with claypans in the buried soils as described by Williams (1945), are very common in the regions where Chernozem, Chestnut, and Brown soils are developed in Peoria and younger loess. The 'double soils' are most distinct near the probable sources of the loess, and the two A horizons blend on the plains a few miles from these theoretical sources. Thus the 'Brady soil' in many places is a part of the modern soil. Schultz and Stout (1948), Lueninghoener (1947), and a number of others are using loess-mantled river terraces as a means of correlating Pleistocene loess deposits and buried soils with various glacial deposits. Much still remains to be done in this field.

The study of radioactive carbon, developed by Libby and associates (1949), is a recent development that will be useful in making final correlations. It is expected that determinations of the proportion of radioactive Carbon-I 4 in peat beds, buried forests, buried soils, and in charcoal from loess-mantled camp-fire sites of ancient man may give us an exact chronology for deposits less than 30,000 years old.

\section{Relationships of Buried Soils to Modern Land Forms and \\ Present-day Soil Profiles}

\section{The Afton soils}

Most of the Nebraska till is buried so deep beneath later deposits that the Aftonian interglacial soils crop out only along deep valley sides. Hence the Afton soil has only the most local effects on present-day soils, landscapes, and land forms in glaciated areas. Little has been done outside of areas of glacial and periglacial deposits to determine whether any soils of Aftonian age still remain there.

Kay and Apfel (1928) describe many sections that include their 'Aftonian soil', which appears to be the uppermost horizon of the Afton soil as we understand it. Following is an excerpt from their description made in a railroad cut $\mathrm{I} \frac{1}{2}$ miles west of Manning, Carroll County, Iowa. We have excluded the description of the overlying Kansas till and Perioa loess.

Soil band, Aftonian, containing carbonaceous material . . 4 inches thick Gumbotil, Nebraskan, gray to drab-colored; few pebbles. The upper six feet is fine-grained, gray, and is less sticky and gumbotil-like than the lower seven feet, which is leached but has some calcareous concretions . . I I feet thick Till, Nebraskan, unleached, oxidized, light yellowish color on dry surface; mottled brownish with gray when damp; many calcareous concretions, especially in upper ten feet

I 7 feet thick 
Elsewhere the gumbotil is described as being very clayey, sticky, and plastic, and breaking to small polyhedral blocks when dry. We consider the second (the gumbotil) horizon to be typical gley. Recent field studies indicate that the upper few feet of 'gumbotil' may be developed from Loveland loess.*

In the deep valleys of southern Iowa landslides are frequent on outcrops of the Afton soil.

\section{The Yarmouth soils}

In parts of Nebraska, Kansas, and perhaps in Texas, some of the buried Yarmouth soils have become exposed and do affect land forms. Short and abrupt changes in slope gradient on hill-sides show where heavy $B$, or gley horizons, more resistant to erosion than friable materials above and below, have been exposed by dissection. The clayey material makes a low ridge or 'shoulder' wherever the old soil is exposed. Most of the Yarmouth soil, however, is either buried beneath later deposits or has been removed entirely by dissection. We do not yet know just which of the old relict but unburied soils of high interfluves and terraces of the southern States may be of Yarmouthian age. For example, a black claypan soil on the Prairie-Chernozem border south of Hutchinson, Kansas, may prove to be Yarmouthian.

Probably some of the old, strongly developed Red Podzolic soils of the southern States may date as far back as Yarmouthian and Kansan times. Certainly many Red Podzolic soils are either relict or, at least, polygenetic. For example, near Memphis, Tennessee, Loveland loess blankets a Red Podzolic soil, much like Ruston fine sandy loam, formed in older materials. This old soil has a light-coloured, leached, sandy loam A horizon of considerable thickness, underlain by a yellowish-red acid clay loam B horizon that grades below to mottled red and yellow acid sandy clay. While it seems likely that this buried soil was developed from materials that were originally calcareous, no calcium carbonate can be detected anywhere in the profile at the present time. Since this buried soil is mantled by Loveland loess, Yarmouthian or possibly greater age is indicated. South-eastward from Memphis, across the upland, the Illinois and Wisconsin loess-mantles become progressively thinner; and in north-eastern Mississippi and northern Alabama one finds Red Podzolic soils at the present surface very much like the one buried near Memphis. Thus physiographic evidence suggests that some of the Red Podzolic soils in the southern States may have begun to develop as early as Kansan time. The Loveland loess, near Memphis, also has a welldeveloped profile in it, buried and beneath the Farmdale and Peoria loesses. Pleistocene geologists are not yet fully agreed on the correlations suggested here for the Memphis environs.

Following are abbreviated notes on the Peorian-Farmdale-Loveland (Illinoian) geologic section that overlies the Red-Podzolic soil mentioned above. Notes were kindly supplied by Dr. W. S. Ligon, Principal Soil Correlator for the Southern States. The location is one mile north of Memphis, Tennessee.

\footnotetext{
* Personal communication from R. W. Simonson and Guy D. Smith.
} 
Exposures of Peorian, Farmdale and Loveland loess, one over the other.

Peorian. About $\mathrm{I}_{5}$ feet thick, calcareous unleached loess capped by 9 feet of leached loess in which Memphis silt loam is developed. Color of unleached loess (Peorian) is distinctly yellower than very pale brown, some distinct coarse mottles of light gray, and many faint mottles of light yellowish-brown. It is a slightly compact, smooth silt.

Farmdale. About 6 feet thick; no distinct profile developed. Material is leached silt, color pale brown to brown, with occasional streaks of very pale brown or gray; compact; hard when dry.

Loveland. Old B horizon is $3 \frac{1}{2}$ to 4 feet thick. Dominantly yellowish-red to red, intimately splotched with faint lighter and darker shades, and a few distinct grayish streaks; texture, silty clay loam to silty clay; hard when dry; medium coarse irregular blocky structure becoming platy when dry. Parent material is 20 feet thick. Strongly variegated; overall color is between yellowish brown and strong brown. Individual colors are yellows, light browns, and grays, of which only a few gray streaks of medium size are prominent. Slightly compact silt with low content of clay. Some soil scientists consider this to be part of the $\mathrm{B}$ horizon.

Strongly developed very old Reddish Prairie and Red Podzolic soils occur on some of the high terraces along the Arkansas, Canadian, and other rivers of Oklahoma and Texas. Lime has been leached to great depth in them; and, in some places, they have been buried by loess at least as old as the Peoria. Where no loess is recognizable, the highterrace and upland surfaces probably have been exposed almost continuously since middle or early Pleistocene times with little change except those accompanying partial dissection.

Many areas of buried Yarmouth soils in Iowa, Missouri, Nebraska, and Kansas seem to have formed under poor drainage. Many have the characteristic sticky grey gley subsoil with rust-brown mottled characteristics of poorly drained soils. Some with claypan or planosolic character appear to have formed on nearly level surfaces, perhaps with fluctuating water-table, as can be seen a few miles north-east of Crete, Nebraska. These gumbo soils are developed both from Kansas till and from periglacial alluvium and loess.

Characteristically, the Yarmouth soil in Kansas till is leached of calcium carbonate, often to depths of 20 to $30 \mathrm{ft}$. (Kay and Apfel, 1928). The grey glacial till is streaked with dark brown and yellowish brown along a network of natural cleavage planes, both under buried soils with brown B horizons, expressing good drainage, and under the grey, sticky, Yarmouth gumbotil. The coloured streaks are 2 to 6 in. thick, and they extend to depths of at least $20 \mathrm{ft}$. in many places. From western Iowa to the western edge of the Kansas glacial till, many of the cleavage planes are lined with pure calcium carbonate, in some places cemented, in others a soft crypto-crystalline deposit from $\frac{1}{2}$ to 2 in. thick. The white bands of calcium carbonate, paralleled by the brown and yellowish streaks, are orientated vertically in one axis; and they form a surface pattern, from above, of small polygons ranging from a foot or two to as much as 3 or $4 \mathrm{ft}$. across. Possibly the lime-filled cracks may have been opened by thin ice wedges during the time the Kansas ice was retreating and before soil formation had advanced very far. Perhaps frost 
phenomena may have prevailed during one of the later glaciations. Deep drying and cracking seems unlikely on flat, marshy land, like that on which Yarmouth gumbo soils were formed.

\section{The Sangamon soils}

The soils of Sangamonian age are by far the most extensive of all of the strongly developed buried soils of central United States and probably of the rest of the country. Throughout their occurrence as far as we know them, the soils are deeply leached and strongly developed in presently humid areas, and leached to lesser depth in drier ones. On nearly level areas, as in southern Illinois and Indiana, drainage was poor in Sangamonian time and buried soils are of gumbo types with gley subsoils (Norton, 1930). However, in much of the area of Sangamon soils we find either dark or light coloured A horizons, with reddishbrown or strong-brown B horizons, that indicate good drainage. Much of the so-called 'Loveland soil' (more properly, Sangamon soil) in Loveland loess is of this kind. It was covered by Wisconsin-aged loess and the land was later dissected. Many so-called 'shoulders' on hill-sides mark the buried or partially buried Sangamon soils. Modern soils, then, are formed from Wisconsin loess and from truncated surfaces of the A, $B$, and $C$ horizons of the Sangamon soil, plus glacial till or bedrock that may have been reached by dissection.

On the Great Plains, it appears from the dark-coloured A horizons and thick, reddish-brown clayey $\mathrm{B}$ horizons that the dominant vegetation probably was grass, and that the dominant well-drained soils were Reddish Prairie soils and reddish Chernozems with maximal textural contrasts between A and B horizons. However, eastward from eastern Nebraska and western Iowa, some of the buried Sangamon soils are podzolic and probably, were developed under forest (Simonson, 194I). The profiles here have many characteristics in common with GreyBrown Podzolic and Red-Yellow Podzolic soils developed under forest cover, and under climates warmer than present ones (Peltier, 1949).

Since the truncated buried soils occur in recently dissected areas, much of the modern soil on the dissected surface is thin. When the land is ploughed and farmed for a few years the dark modern surface soil is partly washed away and the exposed horizons of the truncated buried soil are clearly visible.

In ploughed and eroded hilly fields, between Mankato and Smith Center, Kansas, and near Red Cloud, Nebraska, the yellowish subsoil of the Hastings or Crete soils, developed in Wisconsin loess, shows clearly near the tops of the hill-sides; below that is exposed a broad dark band of the truncated Citellus zone (A horizon) of the Sangamon-Wisconsin soil; farther below is a broad band of the exposed brown or reddishbrown clayey B horizon of the Sangamon soil; and still farther down the slope there is either a yellowish or greyish outcrop of Loveland loess (see Fig. 3) or one of the underlying Cretaceous bedrocks. In eastern Nebraska a similar sequence usually grades into Kansas glacial till.

The authors examined and sampled a section exposed at the Yankee Hill Brick Plant, where Peoria, Farmdale (?), and Loveland loess, and 
older Pleistocene sediments of less-certain age overlie the Fuson kaolinite clay of the Cretaceous.

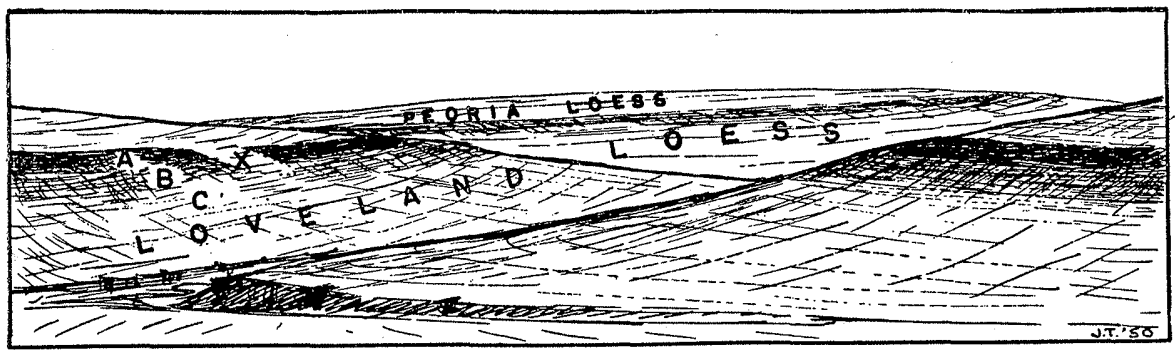

FIG. 3. Sketch of ploughed fields 6 miles north of Red Cloud, Nebraska, showing the Sangamon buried soil (A, B, and C horizons), developed in Loveland loess, cropping out below Peoria loess on hill-sides. $\mathrm{X}$ marks a place where the Sangamonian $\mathrm{A}$ and $\mathrm{B}$ horizons were truncated by a gully before the Peoria loess was deposited.

\section{Section at Yankee Hill Brick Plant, just South of Pioneer Park, Lincoln, Nebraska}

O-I I in. Granular, nearly black, A horizon of Crete silty clay loam.

I I -44 in. Granular to blocky silty clay, B horizon of Crete silty clay loam. Lower part has small hard nodular lime concretions in some places in the cut. In other places there is no evidence of calcium carbonate accumulation.

44 in. -14 ft. 2 in. Leached Peoria loess. Pale brown (dry), to greyish-brown (moist), massive, soft, friable, non-calcareous heavy silt loam; coarse prismatic cleavage; numerous tiny pores; crotovinas numerous ; small faint rusty specks in lower part.

I 4 ft. 2 in. $-\mathrm{I}_{4} \mathrm{ft} .4$ in. Upper Citellus zone (Farmdale loess ?). Light brown (dry), to brown (moist), soft, friable, massive, heavy silt loam; crotovinas; $\mathrm{pH} 7 \cdot 0$.

$\mathrm{I}_{4} \mathrm{ft} .4 \mathrm{in} .-\mathrm{r} 4 \mathrm{ft} .6$ in. Upper Citellus zone. Brown (dry), soft, friable, massive, light silty clay loam; many crotovinas; $\mathrm{pH} 7 \cdot 0$.

r 4 ft. 6 in.- 4 ft. 9 in. Upper Citellus zone. Brown (dry), to dark brown (moist), soft, friable, massive, light silty clay loam; crotovinas; $\mathrm{pH} 7 \cdot 0$.

$\mathrm{I}_{4} \mathrm{ft} .9$ in. $-\mathrm{r} 5 \mathrm{ft} .4$ in. Upper, grading to lower Citellus zone. Mottled brown (dry), to very dark brown (moist), slightly hard, friable, weak-granular light silty clay loam; crotovinas; $\mathrm{pH} 7 \cdot 6$.

I $5 \mathrm{ft} .4$ in. $-16 \mathrm{ft}$. ro in. Lower Citellus zone. A horizon of Sangamon soil. Brown (dry), to very dark brown (moist), slightly hard, friable, weak-granular light silty clay loam; crotovinas; $\mathrm{pH} 7 \cdot 6$.

$\mathrm{r} 6 \mathrm{ft}$. ro in. $-\mathrm{r} 7 \mathrm{ft} .4$ in. Lower Citellus zone. Sangamon $\mathrm{B}_{1}$ horizon. Mottled brown and very pale brown (dry), to mottled very dark brown and pale brown (moist), slightly hard, friable, weak-granular silty clay loam; $\mathrm{pH} 7 \cdot 6$.

I $7 \mathrm{ft} .4$ in. $-17 \mathrm{ft}$. 10 in. Degraded $B_{2}$ horizon of Sangamon soil. Mottled brown and very pale brown (dry), to mottled dark brown and pale brown (moist), hard, friable, weak, irregular-blocky, heavy silty clay loam; $\mathrm{pH} 7 \cdot 6$.

$r_{7} \mathrm{ft}$. ro in. - rg ft. ro in. $B_{21}$ horizon of Sangamon soil. Strong brown (dry), to reddishbrown (moist), hard, friable, weak-blocky, light silty clay; $\mathrm{pH} 7 \cdot 4$.

I9 ft. ro in. $-21 \mathrm{ft} .4$ in. Probably $A_{1}$ horizon of early Sangamon (?) or Illinoian-age soil. Brown (dry), to dark brown (moist), hard, friable, weak coarse blocky, light silty clay; $\mathrm{pH} 7 \cdot 4$. This horizon appears to have been modified by illuviation from the overlying later Sangamon soil.

$21 \mathrm{ft} .4$ in. -23 ft. 2 in. $B_{2}$ horizon of early Sangamon (?) soil. Light brown (dry), to brown (moist), hard, friable, weak-blocky silty clay; $\mathrm{pH} 7 * 4$.

$23 \mathrm{ft} .2$ in. -27 ft. 2 in. $B_{3}$ horizon of early Sangamon (?) soil. Light yellowish-brown (dry), to yellowish-brown (moist), slightly hard, friable, massive silty clay loam; $\mathrm{pH} 7 \cdot 4$. 
$27 \mathrm{ft} .2$ in. $-27 \mathrm{ft} .8$ in. Weakly gleyed horizon of early Sangamon (?) soil. Mottled light brown and reddish-yellow (dry), to mottled brown and strong brown (moist), slightly hard, friable, massive silty clay loam; $\mathrm{pH} 7 \cdot 4$.

$27 \mathrm{ft} .8 \mathrm{in} .-28 \mathrm{ft}$. D horizon, early Sangamon soil. Mottled pale brown and light brown (dry), to brown (moist), hard, friable, massive, sandy clay loam; $\mathrm{pH}_{7 \cdot 4}$. Probably weathered Crete (Illinoian-age) outwash sand.

$28 \mathrm{ft} .-29 \mathrm{ft}$. Probably lower gley horizon of truncated Yarmouth soil. Mottled white and light brown (dry), to light grey and brown (moist), hard, friable, massive silty clay loam. Some black and very dark greyish-brown stains, probably iron and manganese oxides; $\mathrm{pH} 7 \div 4$.

$29 \mathrm{ft} .-37 \mathrm{ft} .2$ in. Sappa silt (?). White (dry), to light brownish-grey (moist), with a few small, rusty spots, streaks, and stains. Soft friable massive silt loam; $\mathrm{pH} 7 \cdot 0$. $37 \mathrm{ft} .2$ in. -42 ft. Yellow (dry), to yellowish-brown (moist), with thin, irregular, wavy bands of white and dark brown; soft, friable, massive, loamy fine sand; $\mathrm{pH} 6.8$. 42-60 ft. Fuson clay (Cretaceous), a red, purple, grey and white mottled kaolinite clay; probably a remnant of a Cretaceous soil.

From central Nebraska the Peoria loess thins southward and southeastward. Near the Nebraska-Kansas line one can bore through the present soil and all of the Wisconsin loess to the Sangamon soil, within Io ft. Still farther south, in southern Lyon County, Kansas, the Sangamon soil is buried only 18 in. to $2 \mathrm{ft}$. below the uneroded upland surface.

\section{The Brady soil}

As pointed out earlier, the Brady soil is developed in loess designated as Peoria and provisionally correlated as of Iowan-Tazewellian age (see Fig. I). Following is a description of the Brady soil made $\mathrm{I} \frac{1}{2}$ miles south of Bignell, Lincoln County, Nebraska, near the original type locality (see Plate II).

$0-4 \mathrm{ft} .4$ in. Modern Chernozem soil. Mapped Holdrege very fine sandy loam.

$4 \mathrm{ft} .4 \mathrm{in}$. $-\mathrm{I}$ I ft. Bignell loess. Light brownish-grey (dry) to dark greyish-brown (moist), massive, very soft, friable silt loam. Calcareous.

I I ft. $-\mathrm{I}$ I ft. 6 in. Transition horizon. Dark greyish-brown (dry) to very dark greyishbrown (moist), massive soft, friable silt loam. Contains secondary calcium carbonate leached down from loess above.

I I ft. 6 in. - I $2 \mathrm{ft} .8$ in. A horizon of Brady soil. Dark greyish-brown (dry), to very dark greyish-brown (moist) weak-prismatic, friable silt loam that breaks easily to weak subangular blocks. Contains calcium carbonate in threads and films, leached down from material above.

I2 ft. 8 in. - I $5 \mathrm{ft}$. B horizon of Brady soil. Pale brown (dry), to dark greyish-brown (moist), weak prismatic silt loam that breaks easily to weak subangular blocks. Contains numerous threads and films of calcium carbonate leached down from loess above.

I 5-20 ft. Peoria loess parent material. Light grey (dry) to greyish-brown (moist), massive, soft, friable, calcareous silt loam. Contains many fossil snails. Indistinctly spotted with strong brown.

Are Reddish Prairie soils relicts?

This leads us to consider the genesis of the Reddish Prairie soils of southern Kansas, Oklahoma, and Texas. When the term 'Reddish Prairie soil' was coined in 1938 (Baldwin et al., 1938), the authors intended it to cover certain acid, grassland soils, with dark A horizons and red or reddish-brown B horizons, that seemed to be correlated with the sub-humid, warm-mesothermal climate of the south-central States. A complicating factor was that a large share of the soils in the Reddish 
Prairie soils zone of Oklahoma are developed from red rocks which obscure any reddish colours that may have developed through soil formation. However, the older of the soils that have developed from non-red bedrocks and old terrace alluvium have redder A and B horizons than most of the Prairie soils of Nebraska, Iowa, and Illinois.

In the region of Reddish Prairie soils some of the clayey rocks have a large proportion of montmorillonite clay in them. On these the soils lack the reddish hues and do not properly belong in the Reddish Prairie group, even though they are in the Reddish Prairie soils zone. They differ little from the Prairie soils of north-central States.

Where a pre-Wisconsin land surface remains uneroded and without a blanket of Peoria loess, we usually find that the well-drained members of soil catenas have reddish-hued B horizons. This is true as far north as south-eastern Nebraska and south-western Iowa. The reddish-hued Sangamon soil can be traced out from under the Wisconsin loess along the Kansas-Nebraska border south of Wymore, Nebraska, and deep into Kansas. In some places the dark silty A horizon of the modern soil may be a small remnant of Peoria loess, but in others it seems likely that the modern soil is entirely a remnant of the soil that began to develop during Sangamonian time. We suggest that the Reddish Prairie soils, supposed to owe their colour to the warmer climate in which most of them are found, may actually owe their properties as much to their great age as to present climatic effects. Geologists have obtained evidence from the study of preserved vegetation and vertebrate fauna that the Sangamonian Interglacial climate was somewhat warmer and moister than that of the recent few thousand years. The warm climate may also have contributed to the redder colour of the soil.

Conversely, where we have traced Peoria loess as far south as Blackwell in northern Oklahoma, we have found that the B horizons of the modern soils are essentially no redder than the $B$ horizons of modern soils in the cooler environment of Iowa, Nebraska, and the Dakotas. We must conclude, then, either that the post-Peorian climate has been too cool or that the time has been too short to produce a Reddish Prairie soil in Peoria loess at Blackwell.

Therefore we offer the hypothesis that the true Reddish Prairie soils may owe their colour and other characteristics more to their age and to former warmer climates than they do to the present climatic conditions under which they occur. If this hypothesis is reasonable, we shall have to re-examine our classification of the soils in the Reddish Prairie soils zone. If, as we expect, we can demonstrate that all the soils that began to develop from non-red materials during middle and late Wisconsin glacial time lack the reddish hues, we shall have to recognize that some true Prairie soils exist in the zone of Reddish Prairie soils.

Parallel with the occurrence of reddish soils in the zone of Prairie soils, and vice versa, are many examples of Chernozem-like and Chestnut-like soils with reddish-hued $B$ horizons in the zones of Chernozems and Chestnut soils. In every case we know, these reddish hues are associated with relict or polygenetic soils which, for the most part, remain buried beneath Peorian loess. 


\section{Are Red Podzolic soils relicts?}

We find a parallelism with the situation on the Great Plains in the loess belt east of the Mississippi River. The Memphis and Grenada soils are developed in Peoria loess southward from southern Indiana and Illinois almost to Baton Rouge, Louisiana. Soils of these two series have morphological characteristics more like Grey-Brown Podzolic soils than like the Red-Yellow Podzolic soils with which the greater part of them are associated. Marbut (1935) called attention to the fact that Memphis and Grenada soils belong in the Grey-Brown Podzolic group, and he attributed their presence in southern States to their relative youth.

Not only do the Grey-Brown Podzolic soils extend deep into the zone of Red-Yellow Podzolic soils, but old podzolized soils with reddish B horizons, resembling Red Podzolic soils, occur in southern Indiana, Ohio, and Pennsylvania. The Orleans silt loam of Washington County, Indiana (Miller and Higbee, I939), is an example. Perhaps these old soils should be classed as Grey-Brown Podzolic soils of maximal development; perhaps they are relict Red Podzolic soils. Many of the old red soils of the Ohio Valley are buried beneath a thin mantle of Peoria loess.

Thorp and Smith (r949), who reported soils with morphology like the Grey-Brown Podzolic soils in Puerto Rico and in Assam, under humid tropical climates, ascribed the phenomenon to the relative youth of the soils. In other words, it appears that Grey-Brown Podzolic soils generally may be younger than Red-Yellow Podzolic soils, especially than the Red Podzolic soils like the Ruston, Orangeburg, and Cecil soils, where the two great groups are associated.

We have made many accurate determinations of soil colours, based on the Munsell Color Charts (Nickerson, I94I), in order to try to see what relationship may exist between soil colour and soils of various ages. Darkness and degree of chroma saturation vary from place to place, but the hues of modern soils developed in Wisconsin-aged loess, younger than Farmdale, are nearly everywhere no redder than Munsell $7.5 \mathrm{YR}$, and usually no redder than Io YR. Exceptions are in a few places like southern Kansas, western Oklahoma, and northern Texas, where some of the eolian materials came from red rocks or red river sediments.

We think that a careful study of hue of parent materials compared to the hue of B horizons of zonal soils may eventually be used as a tool to help judge soil age.

\section{Buried soils and soil fertility}

Some buried soils have a bearing on the fertility of modern soils. In parts of south-eastern Nebraska and north-eastern Kansas where farmers have been ploughing the soil for at least 50 years, much surface soil, formed predominantly in Wisconsin loess, has been washed away. Erosion has exposed the reddish-brown B horizons of Sangamon and perhaps of the Yarmouth soils on many slopes. Corn planted on soils of this kind grows well where the dark surface soil remains intact; but the crop shows signs of nitrogen starvation and severe phosphorus deficiency where the reddish buried soils have been exposed. Where the solum has developed entirely from Peoria loess or from unleached Kansas till, 
phosphorus deficiency in corn is less evident, even though there may be a shortage of nitrogen. Thus it appears that the Sangamon soil contains less easily available phosphorus than the modern soils, formed either from the Wisconsin-aged deposits or from recently exposed, but relatively little weathered, Kansas glacial till. Deficiencies of this kind make it very difficult to establish permanent vegetation for erosion control on eroded hill-sides.

\section{Future work}

Old soils, both exposed and buried, on the High Plains in southeastern Colorado, south-western Kansas, western Oklahoma, and the 'Panhandle' of Texas need further study. We know that the Peoria loess thins south-eastward across the High Plains, from eastern Colorado, and that a buried soil with reddish clayey $B$ and caliche horizons approaches the surface in the vicinity of Amarillo, Texas. This region is too complicated to be reviewed here. Here the Reddish Chestnut soils grade westward into the Reddish-Brown soils of the semi-arid southern steppes, and then to the Red Desert soils of truly arid regions. We may think of these older soils as relicts-essentially the products of former environmental conditions, but modified by the soil-forming factors of today.

Geologists, geomorphologists, and soil scientists have recently renewed their interest in Pleistocene geology and in its buried soils. We expect that co-operative studies, some of which are now in progress, will shed much light on the history of 'fossil' and modern soils, and will give us a better basis on which to evaluate the time factor in soil formation.

\section{REFERENCES}

ALDEN, W. C. 1932. Physiography and glacial geology of eastern Montana and adjacent areas. U.S. Geol. Surv. Prof. Pap. No. I74.

BAKER, W. G. 1924. A light-colored zone of subsoil in southern Iowa. Iowa Acad. Sci. Proc. 31, 347-9.

Baldwin, M., KellogG, C. E., and Thorp, J. 1938. Soil classification. U.S. Dept. Agric. Yearbook, r938, 979-100r.

BRYAN, K. 1938. Los suelos complejos y fosiles de la altiplanicie de Mexico, en relación a los cambios climaticos. Bol. Soc. Geolog. Mejicana, 13, I-20.

- and AlBRitToN, C. C., JR. I 943. Soil phenomena as evidence of climatic changes. Amer. J. Sci. 241, $469-90$.

BRYAN, W. H. 1939. The red earth residuals and their significance in south-eastern Queensland. Proc. Roy. Soc. Queensland, 1, New Series, 21-32.

Condra, G. E., ReEd, E. C., and Gordon, E. D. 1947. Correlation of the Pleistocene deposits of Nebraska. Nebr. Geol. Surv. Bull. 15, 73 pp.

Frye, J. C. I949. Use of fossil soils in Kansas Pleistocene stratigraphy. Kansas Acad. Sci. Trans. 52, 478-82.

- and LeONARD, A. B. I949. Pleistocene stratigraphic sequence in north-eastern Kansas. Amer. J. Sci. 247, 883-99.

Plummer, N., Runnels, R. T., and Hladik, W. B. I949. Ceramic utilization of northern Kansas Pleistocene loesses and fossil soils. State Geol. Surv. of Kansas, Bull. 82, Pt. 3, 49-I24.

Joffe, J. S. 1936. Pedology, 575 pp. Rutgers Univ. Press, New Brunswick.

KAY, G. F. I916. Gumbotil, a new term in Pleistocene geology. Science, 44, 637-8.

1949. Pleistocene history and early man in America. Bull. Geol. Soc. Amer. 50, $453-63$. 
KAY and APFEL, E. T. I928. The pre-Illinoian Pleistocene geology of Iowa. Iowa Geol. Surv. Rpts. 34, I-304.

and Graham, J. B. r 943. The Illinoian and post-Illinoian Pleistocene geology of Iowa. Ibid. 38, 262 pp.

and Pearce, J. N. 1920. The origin of gumbotil. J. Geol. 28, 89-125.

Krokos, V. I. 1926. Le loess et les sols fossiles du sud-ouest de l'Ucraine. Actes de la IVème Conf. Internat. de Pédologie, Sec. 3, 3, 482-8.

- 1927. The loess formations of the Ukrainia. In Contributions to the Study of the Soils of Ukrainia. No. 6, pp. $x^{-1} 3$.

Leighton, M. M., and MacClintock, P. 1930. Weathered zones of the drift-sheets of Illinois. J. Geol. 38, 28-53.

and Willman, H. B. r949. Loess formations of Mississippi Valley. (Abstract) Bull. Geol. Soc. Amer. 60, r904-5.

LEONARD, A. B. 1950. A Yarmouthian molluscan fauna in the midcontinent region of the United States. Univ. Kansas Paleontological Contrib., Mollusca, article 3, $\mathrm{I}-48$.

LEVERETT, F. I $898 a$. The weathered zone (Sangamon) between the Iowan loess and Illinoian till sheet. J. Geol. 6, I7I-8r.

- $1898 \mathrm{~b}$. The weathered zone (Yarmouth) between the Illinoian and Kansan till sheets. Ibid. 6, 238-43.

- $898 \mathrm{c}$. The Peorian soil and weathered zone (Toronto formation?). Ibid. 6 , 244-9.

Libby, W. F., Anderson, E. C., and Arnold, J. R. 1949. Age determination by radiocarbon content; world-wide assay of natural radiocarbon. Science, 109, $227-8$.

Lueninghoener, G. C. r947. The post-Kansan geologic history of the lower Platte Valley area. Univ. Nebr. Studies, New Series, No. 2.

Lugn, A. L. I935. The Pleistocene geology of Nebraska. Nebr. Geol. Surv. Bull. No. ro, 2nd Series, $223 \mathrm{pp}$.

Marbut, C. F. 1935. Atlas of American Agriculture, Pt. 3, Soils of the United States. Washington, 1935 .

Miller, J. T., and Higree, H. W. 1939. Soil Survey, Washington County, Indiana. U.S. Dept. Agric. and Purdue Agric. Expt. Sta., Series I932, No. 36.

Mohr, E. C. J. I 944 . The Soils of Equatorial Regions, with special reference to the Netherlands East Indies. Trans. by R. L. Pendleton. Ann Arbor, $766 \mathrm{pp}$.

Movius, H. L., JR. I949. Lower Paleolithic archaeology in southern Asia and the Far East. Studies in Physical Anthropology, No. I, pp. 17-82.

National Research Council Committee, R. F. Flint, chairman, i 945. Glacial map of North America. Geol. Soc. Amer., publishers.

Nickerson, D. r94I. Central notations for ISCC-NBS color names. J. Opt. Soc. Amer. 31, 587-9r.

Norton, E. A. I930. Succession of soil profiles along Mississippi River in Illinois. Amer. Soil Surv. Assn. Bull. 11, r 58-6o.

Peltier, L. C. r949. Pleistocene terraces of the Susquehanna River, Pennsylvania. Pennsylvania Geol. Surv. 4th Series, Bull. G 23, I58 pp.

Pendleton, R. L., Ch'ang, L. C., Chen, W., and Hou, K. C. I932. Soil survey of the Salachi Area, Suiyuan Province, China. Geol. Surv. China Soil Bull. No. 4, $43 \mathrm{pp}$.

Soil Bull. No. II, I35 pp:

Polynov, B. B. 1927. Contributions of Russian scientists to paleopedology. Russian Pedological Investig. 8, 33 pp.

Schultz, C. B., and Stout, T. M. 1945. Pleistocene loess deposits of Nebraska. Amer. J. Sci. 243, No. 5, $231-44$.

1948. Pleistocene mammals and terraces in the Great Plains. Bull. Geol. Soc. Amer. 59, 553-87.

Simonson, R. W. I94r. Studies of buried soils formed from till in Iowa. Soil Sci. Soc. Amer. Proc. 6, 373-8r.

SwINEFord, A. r949. Source area of Great Plains Pleistocene volcanic ash. J. Geol. $57,307-1 \mathrm{x}$. 
THORP, J. I935. Soil profile studies as an aid to understanding recent geology. Bull. Geol. Soc. China, 14, 3, 359-93.

- 1936. Geography of the Soils of China. Nat. Geol. Survey of China, Nanking, $552 \mathrm{pp}$.

- and Smith, G. D. I949. Higher categories of soil classification; order, suborder, and great soil groups. Soil Sci. 67, I I 7-26.

Willrams, B. H. 1945. Sequence of soil profiles in loess. Amer. J. Sci. 243, No. 5, $27 \mathrm{I}-7$.

Worthen, A. H. 1866. Geology of Illinois. Geol. Surv. Illinois, 1, 523 pp.

(Received II August I950) 


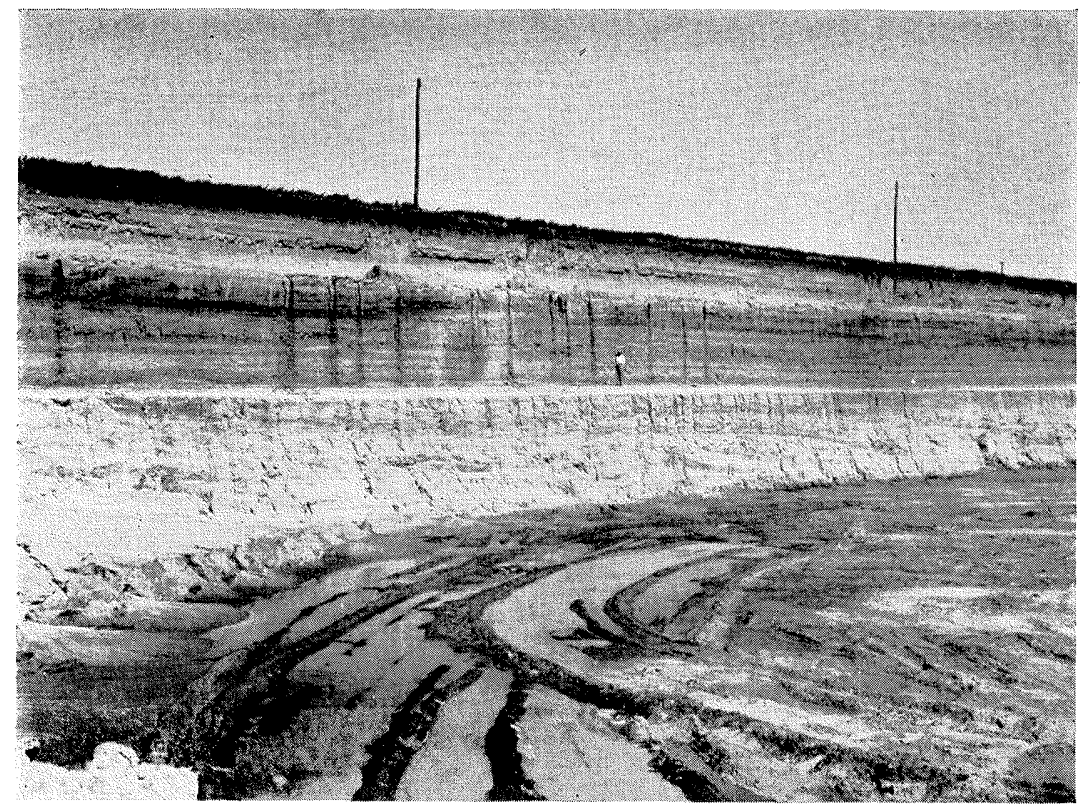

A (from top to bottom). Modern soil, Crete silty clay loam, in Peoria loess; dark band is Sangamon soil with transition above to Peoria loess; dark band at level of man's head is probably early Sangamonian soil; the man is standing on the truncated Yarmouthian soil and silt; water stands on the top of the Fuson kaolinite clay, a truncated Cretaceous soil.

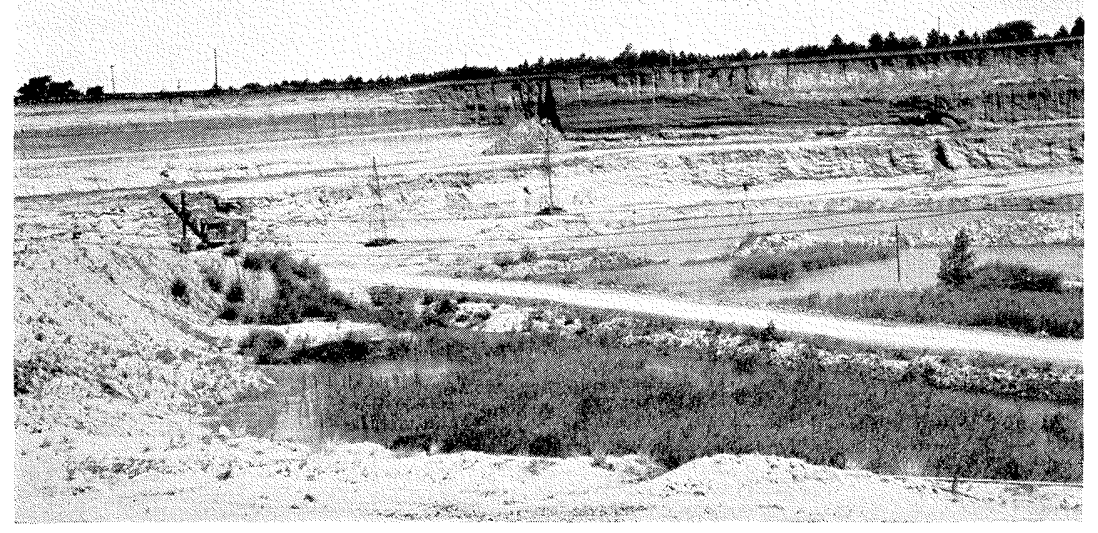

B. General view of the pit. Steam shovel is working at face of Fuson clay.

Plate I. Clay pit at Yankee Hill Brick Plant, Lincoln, Nebraska

J. THORP, W. M. JOHNSON, E. C. REED POST-PLIOCENE BURIED SOILS 


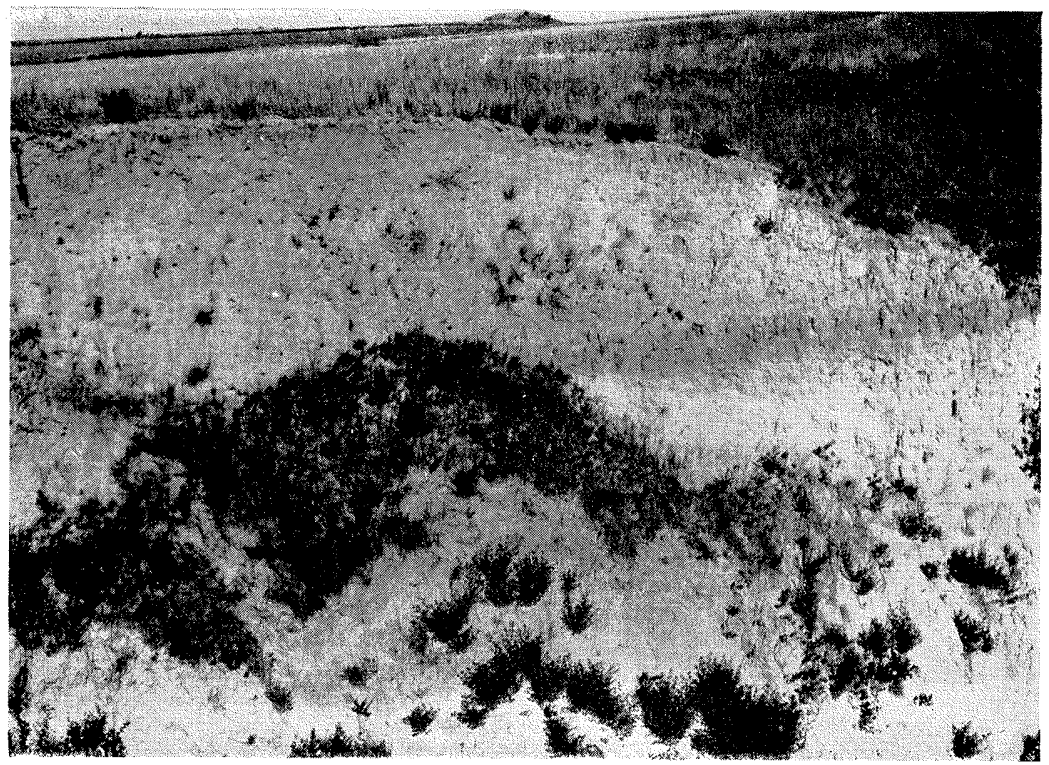

A. Brady soil, developed in Peoria loess and buried by Bignell (late Wisconsinian?) loess one and a half miles south of Bignell, Nebraska. Holdrege very fine sandy loam, the modern Chernozem at this site, has been truncated by recent erosion.

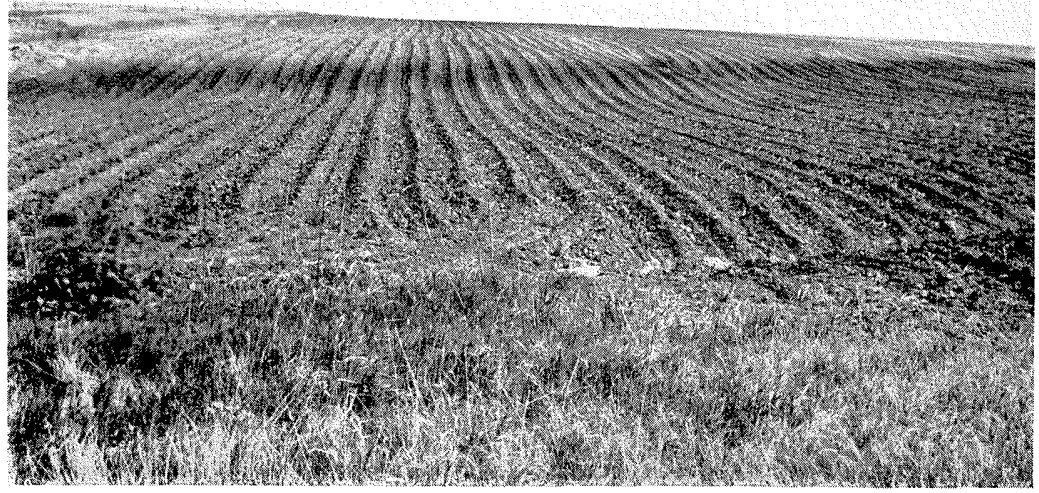

B. Sangamon soil developed in Loveland (Illinoian) loess and buried by Peqria loess, exposed in corn (maize) field, near Smith Center, Kansas. Note low scarp or 'shoulder' where Sangamon soil is exposed.

\section{Plate II}

J. THORP, W. M. JOHNSON, E. C. REED POST-PLIOCENE BURIED SOILS 